\title{
Response of Human and Rat Small Intestinal Mucosa to Oral Administration of Saccharomyces boulardii
}

\author{
JEAN-PAUl BUTS, PAUL BERNASCONI, MARIE-PAULE VAN CRAYNEST, PAUL MALDAGUE, \\ AND ROGER DE MEYER \\ Laboratory of Pediatric Gastroenterology and Nutrition, and Unit of Experimental Pathology, University of \\ Louvain, Brussels, Belgitum; Biocodex Laboratories, Montrouge, France
}

\begin{abstract}
To evaluate the response of the small intestinal mucosa to Saccharomyces boulardii $(S . b$.$) , a yeast$ widely used in some countries as an adjuvant drug with oral antimicrobial therapy, seven healthy adult volunteers were treated with high doses of lyophilized $S . b .(250 \mathrm{mg}$ four times per day) for 2 wk. A peroral jejunal suction biopsy was performed on days 0 and 15 of the study. Compared to the initial biopsy, histological examination of the posttrial biopsy revealed no morphological alteration nor change in villus height or crypt depth. After treatment, the specific activity (per $U$ protein) of sucrase, lactase, and maltase was, respectively, increased by $82 \%(p<0.05)$ $77 \%(p<0.05)$, and $75 \%(p<0.05)$ over the basal activity of the enzymes measured on day 0 , whereas mucosal protein content remained unchanged. Similar findings were found in the jejunum of adult rats treated for 5 days with either viable or killed $S . b$. cells. The changes in total enzyme activity (per jejunal segment) paralleled the changes in specific enzyme activity. In vitro assays on freshly prepared suspensions of $S . b .\left(6.0 \times 10^{8}\right.$ viable cells/ $\mathrm{ml}$ ) evidenced a high activity for sucrase (mean $\pm \mathrm{SE}: 8$ $364 \pm 1280 \mathrm{U} \cdot \mathrm{g} \cdot$ protein $^{-1}$ ) but no maltase, neutral lactase, acid $\beta$-galactosidase, or aminopeptidase activity. To determine whether treatment with $S . b$. could influence the incorporation rate of neutral lactase into the brush border membrane, 14-day-old sucklings treated either with saline or with $S$.b. were given intraperitoneally a dose of $20 \mu \mathrm{Ci}$ $\mathrm{D}-\left[1^{14} \mathrm{C}\right]$ glucosamine 3 hours before sacrifice. Neutral lactase was isolated on SDS-PAGE of purified BBM. The amount of lactase protein eluted from the gel slices was similar in treated rats (mean \pm SE: $0.026 \pm 0.003)$ and in controls $(0.021 \pm 0.005 \mathrm{mg}$ protein $/ \mathrm{ml})$. Expressed per milligram of brush border membrane lactase protein, there was no significant difference in the incorporation rate of labelled glucosamine between treated rats (mean $\pm \mathrm{SE}: 8$ $167 \pm 1622 \mathrm{dpm} \cdot \mathrm{mg}$ protein $\left.{ }^{-1}\right)$ and controls (9 602 \pm 1 $803 \mathrm{dpm} \cdot \mathrm{mg}$ protein $\left.^{-1}\right)$. In conclusion, short-term oral treatment of human volunteers and rats with $S . b$. is associated with a marked increase in the activity of disaccharidases without morphological alteration of the intestinal mucosa. Our findings do not suggest an effect of $S . b$. on the incorporation rate of enzymes into the brush border membrane. (Pediatr Res 20: 192-196, 1986)
\end{abstract}

Received January 18. 1985: accepted September 20,1985.

Address correspondence and reprint requests to Dr. J. P. Buts, Department of Pediatries. Cliniques Universitaires St. Luc, 10. Avenue Hippocrate, B-1200 Brussels. Belgium.

Supported by Grant 3.4551/82 from the "Fonds de la Recherche Scientifique Medicale" (FRSM) Belgium.

\author{
Abbreviations \\ S.b., Saccharomyces boulardii \\ BBM, brush border membrane
}

Lyophilized preparations of the yeast S.b. (Ultra-Levure, Biocodex, Montrouge, France) are widely prescribed in some Western European countries mainly as adjuvant oral therapy to antimicrobial drugs. Previous clinical trials $(1-3)$ have suggested that the association of $S . b$. with broad spectrum antibiotics has beneficial effects in preventing the occurrence of complications linked to changes in the normal gut microflora. Although adverse or toxic reactions related to $S . b$. treatment have not been observed in adults and children, the response of the intact small intestine to large doses of lyophilized S.b. cells is not known. The purpose of the present study is to assess the morphological and enzymatic responses of human and rat small intestine mucosa to oral administration of $S . b$.

\section{SUBJECTS}

Seven healthy young adults, six males and one female, with a mean age of $20 \mathrm{yr}$ were enrolled as subjects for the pharmacological assay. The study was approved by the Hospital Ethical Committee on research involving human subjects. Before enrollment, the purpose of the study and the procedures were explained in detail and written consent was obtained from each of the volunteers. All subjects were Caucasian. None had diarrhea nor were there any other signs to suggest impaired lactose absorption. None was taking drugs at the time of the study.

\section{EXPERIMENTAL DESIGN AND METHODS}

Human studies. S.b. (Ultra-Levure) was prepared in a lyophilized form (250 mg per batch having a biological activity of 9.4 $\times 10^{9}$ viable cells) by the manufacturer (Biocodex). Each batch was identical in composition and contained no carbohydrate. The subjects were given oral doses of $250 \mathrm{mg}$ S.b. four times a day from day 1 to day 14 of the study. A peroral suction biopsy was performed in each subject with the Carrey capsule on day 0 and on 15. All the tissue specimens were obtained from the duodeno-jejunal junction under fluoroscopic control. The specimens were processed for the following examinations: light microscopy, morphometric measurements, and microvillous enzyme assays.

Animal Studies. Experimental design. Three litters (six rats each) of 30-day-old Wistar rats, weighing about $50 \mathrm{~g}$, were used. All animals were kept in polystyrene cages in an air-conditioned 
room at $21 \pm 1^{\circ} \mathrm{C}$ with a $12 \mathrm{~h}$ light-dark cycle. They were fed ad libitum a solid standard stock diet (N 103, UAR, Villemoisson-sur-Orge, France) and had free access to water. A dose of 25 mg lyophilized $S . b$. was administered orally to each rat three times per day from day 0 to day 5 of the study. The lyophilized preparation was identical in composition and in biological activity to that used for the human subjects. Each dose $(25 \mathrm{mg})$ was dissolved in $0.5 \mathrm{ml}$ of $0.9 \%$ saline. The second group of six rats was treated following the same schedule with $S . b$. cells killed by heating $\left(50 \mathrm{~min}\right.$ at $\left.120^{\circ} \mathrm{C}\right)$. The control group received an equal volume of saline.

Preparation of tissues. On the day of sacrifice (day 5), at 0800 $\mathrm{h}$, the rats were killed rapidly by decapitation and the small intestine from the pylorus to the ileocecal valve was immediately excised. After rinsing it in $0.9 \%$ cold saline, the total length was measured (4) and divided into two equal segments. The proximal half was defined as the jejunum and the distal half as the ileum. Each jejunal segment was promptly opened lengthwise and the mucosa was scraped off between glass slides and weighed. It was thereafter wrapped in parafilm and frozen in liquid nitrogen until use.

Morphological analysis. For light microscopy, specimens of human intestinal biopsies and of rat jejunum (first $2 \mathrm{~cm}$ distal to the duodenojejunal ligament) were fixed in a $10 \%$ formaldehyde solution, sectioned, and stained with hematoxylin and eosin. Morphometric measurements were performed with a calibrated projective Visopan microscope (Reichert).

Enzyme assays. Enzyme activities were determined in homogenates of human intestinal biopsies and of rat full-thickness mucosa. Assays were also performed in vitro on freshly prepared homogenates of $S . b$. cells containing $6.0 \times 10^{8}$ viable cells per $\mathrm{ml}$. All assays were performed within 1 wk of collection. Sucrase, neutral lactase, and maltase activity were determined by the method of Dahlqvist (5) and expressed in units (micromoles of substrate hydrolyzed per min at $37^{\circ} \mathrm{C}$ ) per $\mathrm{g}$ protein. Mucosal protein was measured by the method of Lowry et al. (6). Acid $\beta$ galactosidase activity was assayed by the method of Koldovsky et al. (7) and alkaline phosphatase by the method of Bessey et al. (8). Activities were expressed as $\mu \mathrm{mol}$ of para or orthonitrophenol liberated per min per $g$ protein. Aminopeptidase activity was assessed by the method of Maroux et al. (9) and activities expressed as $\mu \mathrm{mol}$ of nitroanilin formed per min per $\mathrm{g}$ protein.

Incorporation studies. To determine whether treatment with $S . b$. could affect the incorporation rate of enzymes into the BBM, we studied the in vivo incorporation rate of $\mathrm{D}-\left[1{ }^{14} \mathrm{C}\right]$ glucosamine into the protein band corresponding to neutral lactase of young suckling rats treated with $S . h$. or with saline. Two litters of 10 day-old rats were treated orally with $S . b .(25 \mathrm{mg}$ of lyophilized $S . h$. in $0.5 \mathrm{ml}$ saline 3 times per day) from day 10 up to day 14 postpartum. The last dose was given $3 \mathrm{~h}$ before sacrifice. Littermates served as controls and were given an equal amount of the vehicle following the same schedule. On the day of the experiment (day 14), $20 \mu \mathrm{Ci}$ of D-[ $\left[{ }^{14} \mathrm{C}\right]$ glucosamine (sp. act. $54 \mathrm{mCi}$ / mmol, New England Nuclear, Dreieich, Germany) were injected intraperitoneally to each animal at $0730 \mathrm{~h}$, and rats were killed $3 \mathrm{~h}$ after the injection. BBM were isolated and purified following the procedure of Schmitz et al. (10).

Preliminary assays revealed that lactase specific activity was about 16- to 20-fold higher in the BBM fraction $\left(\mathrm{P}_{2}\right)$ than in the crude homogenate. BBM proteins were separated on gradient $(5-15 \%)$ polyacrylamide gels in the presence of sodium dodecyl sulfate $2.3 \%(\mathrm{w} / \mathrm{v})$, following a method adapted from Laemmli (11). Each sample layered onto the gels contained $200 \mu \mathrm{g} \mathrm{BBM}$ protein in an appropriate volume of buffer $(29-56 \mu l)$ with sodium dodecyl sulfate $2.3 \%$ and traces of bromophenol blue.

Solubilization of protein from gel-slices was performed according to Djondjurov and Holtzer (12). For the determination of protein, a micromodification of the method reported by Lowry et al. (6) was used (13). Preliminary assays revealed that the recovery of protein eluted from the gel slices was 95\%. The techniques for assay of lactase in gel-slices eluates have been described in detail elsewhere (14). To measure ${ }^{14} \mathrm{C}$ radioactivity incorporated into lactase protein, each gel slice was homogenized until completely disintegrated in $1 \mathrm{ml}$ of cold $10 \%$ tricloroacetic acid-30\% ethanol solution. The homogenates were centrifuged $10 \mathrm{~min}$ at $10,000 \mathrm{rpm}$. The supernatants were discarded and the same procedure was repeated four more times. Finally, after the last centrifugation, the pellets of completely decolorized gel slices were treated with $1 \mathrm{ml}$ of $0.1 \mathrm{~N} \mathrm{NaOH}$ and shaken for $2 \mathrm{~h}$ at $37^{\circ}$ C. Thereafter, the material was recentrifuged for $10 \mathrm{~min}$ at 12,000 $\mathrm{rpm}$ and the supernatants carefully collected. It was possible to recover about $0.85 \mathrm{ml}$ of the original volume used. The recovered volumes were returned to $1 \mathrm{ml}$ with $0.1 \mathrm{~N} \mathrm{NaOH}$ and assayed for protein. Protein aliquots of the $\mathrm{NaOH}$ eluates $(200 \mu \mathrm{l})$ were counted in $10 \mathrm{ml}$ Instagel. ${ }^{14} \mathrm{C}$ radioactivity was determined with a Beckman Scintillation counter. Incorporation rates were expressed as dpm per mg brush border protein ${ }^{-1}$.

All results are given as mean $\pm \mathrm{SE}$. Difference between mean values were tested for statistical significance $(p<0.05)$ using the Wilcoxon matched-pairs signed-ranks test for human studies and the one way analysis of variance and/or the Student's $t$ test for animal studies.

\section{RESULTS}

In vitro assays. Preliminary enzymatic assays were conducted in vitro on freshly prepared suspensions of viable $S . b$. cells (Table 1). Concentrated preparations of $S . b$. cells exhibited high sucrase activity and very low alkaline phosphatase activity. No maltase, neutral and acid $\beta$-galactosidase, or aminopeptidase activities could be detected, despite variations in substrate concentration, $\mathrm{pH}$, and incubation conditions.

Human studies. The duration of the study was 15 days. At the doses of $S . b$. given, the volunteers reported no disturbances in their routine activities and were asymptomatic. The drug produced no toxic reaction or digestive side effect such as abdominal discomfort, meteorism, diarrhea, obstipation, nausea, or vomiting. Physical examination of the subjects was unremarkable and all had normal weight for height. Histological examination of the intestinal biopsies taken on day 0 and day 15 revealed no structural abnormality, and measurements of villus height and of crypt depth showed no significant change. Mean villus height was $262 \pm 14 \mathrm{~m} \mu$ on day 0 and $258 \pm 16 \mathrm{~m} \mu$ on day 15 , whereas the mean values of crypt depth were respectively $152 \pm 11 \mathrm{~m} \mu$ (day 0) and $147 \pm 9.7 \mathrm{~m} \mu$ (day 15 ).

The results of mucosal disaccharidase activities are depicted in Figure 1. Oral treatment with S.b. cells resulted in significant ( $p$ $<0.05$ ) increases in the activity of the three disaccharidases. On day 15 , the specific activity of sucrase, lactase, and maltase were

Table 1. In vitro enzymatic assays on viable S.b. cells suspension

\begin{tabular}{|c|c|}
\hline Parameters & Mean $\pm \mathrm{SE}$ \\
\hline No. of $S . b$. cells $/ \mathrm{ml}$ & $6.0 \pm 10^{8}$ \\
\hline Protein $(\mathrm{mg} / \mathrm{ml})$ & $3.05 \pm 0.55^{*}$ \\
\hline Sucrase activity $\dagger$ & $8364 \pm 1280$ \\
\hline Neutral lactasef & NA $\dot{\ddagger}$ \\
\hline Maltase $\dagger$ & $\mathrm{NA}$ \\
\hline Alkaline phosphatases $\$$ & 10.7 \\
\hline Acid $\beta$-galactosidase $\|$ & NA \\
\hline Aminopeptidasef & $\mathrm{NA}$ \\
\hline
\end{tabular}

* Mean \pm SE of three determinations.

$\dagger \mu \mathrm{mol}$ of substrate hydrolyzed per min per g protein.

$\ddagger$ No activity detected.

$\S \mu \mathrm{mol}$ of $p$-nitrophenol formed per min per $\mathrm{g}$ protein.

$\| \mu \mathrm{mol}$ of $O$-nitrophenol formed per min per g protein.

$\uparrow \mu \mathrm{mol}$ of nitroanilin formed per min per $\mathrm{g}$ protein. 
increased respectively 82,77 , and $75 \%$ over the basal activity of the enzymes measured at the same level of the duodenojejunum on day 0 . Enzyme changes expressed per $\mathrm{mg}$ of intestinal mucosa, paralleled the changes in activity per mg of mucosal protein, the protein concentration of the intestinal mucosa being unchanged (day 0: $118 \pm 4$, day 15: $103 \pm 3,7 \mathrm{mg}$ protein $\cdot g$ mucosa $^{-1}$ ).

Animal studies. Adult rats treated orally with viable $S . b$. cells suspended in $0.9 \%$ saline and control animals receiving saline alone appeared healthy. During the experimental period (5 days), the growth rate was similar in both groups (body weight gain: $9.14 \pm 0.2 \mathrm{~g}$ treated group versus $10 \pm 0.5 \mathrm{~g}$ control group). Jejunal rings obtained from treated and control animals showed

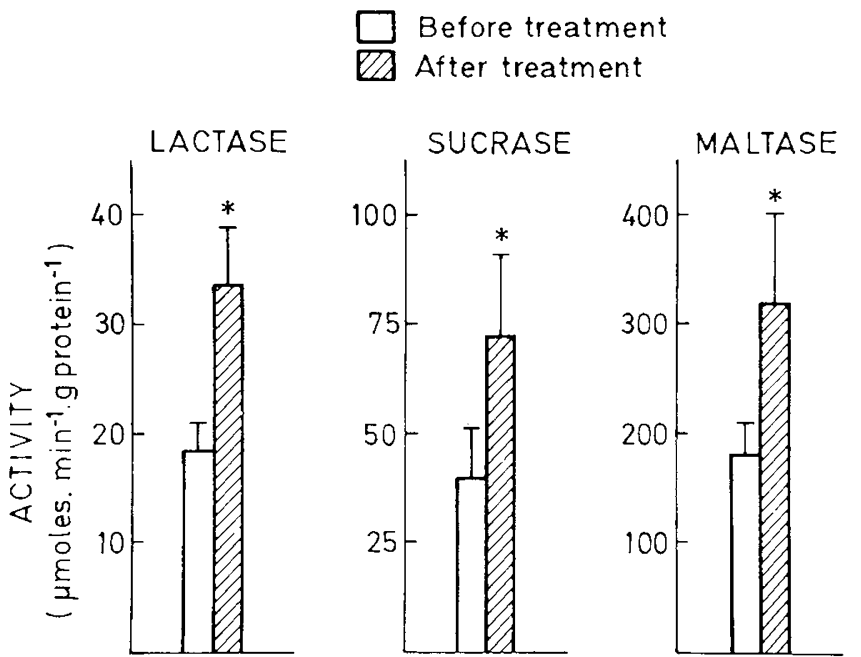

Fig. 1. Changes in mucosal specific activity of sucrase, lactase, and maltase after 14 days of oral treatment with $S . b$. (seven volunteers). The values are mean $\pm \mathrm{SE},{ }^{*} p<0.05$ (Wilcoxon matched-pairs signed-ranks test). no morphological alteration. As illustrated in Figure 2, the presence of $S . b$. cells could be clearly identified in tissue sections of treated rats. The yeasts were located in the lumen or were in contact with villus cells without penetration into the epithelium. The villus cells appeared well differentiated and there was no evidence of focal or diffuse inflamatory reaction. Measurements of villus height and crypt depth were equivalent in treated and control animals. The changes in mucosal disaccharidase activities are presented in Table 2. Compared to controls, rats treated with either viable or killed $S . b$. showed significant increases in the specific activity of lactase $(+109$ to $150 \%)$, sucrase $(+128$ to $157 \%)$, and maltase $(+73$ to $104 \%)$, over the control levels. Again, the total protein content of the jejunal mucosa was similar in the three groups (Table 2). There was no difference in jejunal mucosal weight so that the changes in total enzyme activity (per intestinal segment) were comparable to the changes in specific enzyme activity. In rats treated with viable $S . b$. cells the increase in total aminopeptidase activity was slight $(+17 \%)$ and not

Table 2. Disaccharidase activities in the jejunum of 30-day-old rats treated with either viable or killed S.b. cells and of controls

\begin{tabular}{lccc}
\hline & $\begin{array}{c}\text { Viable } S . b . \\
\text { cells }\end{array}$ & $\begin{array}{c}\text { Killed } S . b . \\
\text { cells }\end{array}$ & Controls \\
\hline$n$ & 6 & 6 & 6 \\
Lactase* $_{\text {Sucrase* }}$ & $5.5 \pm 1.1 \dagger$ & $4.6 \pm 0.8 \ddagger$ & $2.2 \pm 0.6$ \\
Maltase* & $59 \pm 9.1 \dagger$ & $52 \pm 7.6 \dagger$ & $23 \pm 4.6$ \\
Protein & $286 \pm 35 \dagger$ & $243 \pm 25 \dagger$ & $140 \pm 18$ \\
(mg g mu- & $122 \pm 6.8$ & $117 \pm 3.5$ & $126 \pm 1.1$ \\
cosa $^{-1}$ ) & & & \\
\hline
\end{tabular}

* $\mu \mathrm{mol}$ of substrate hydrolyzed per min per $\mathrm{g}$ protein. Results are mean $\pm \mathrm{SE}$.

$\dagger p<0.05$.

$\ddagger p=0.05$ versus controls.

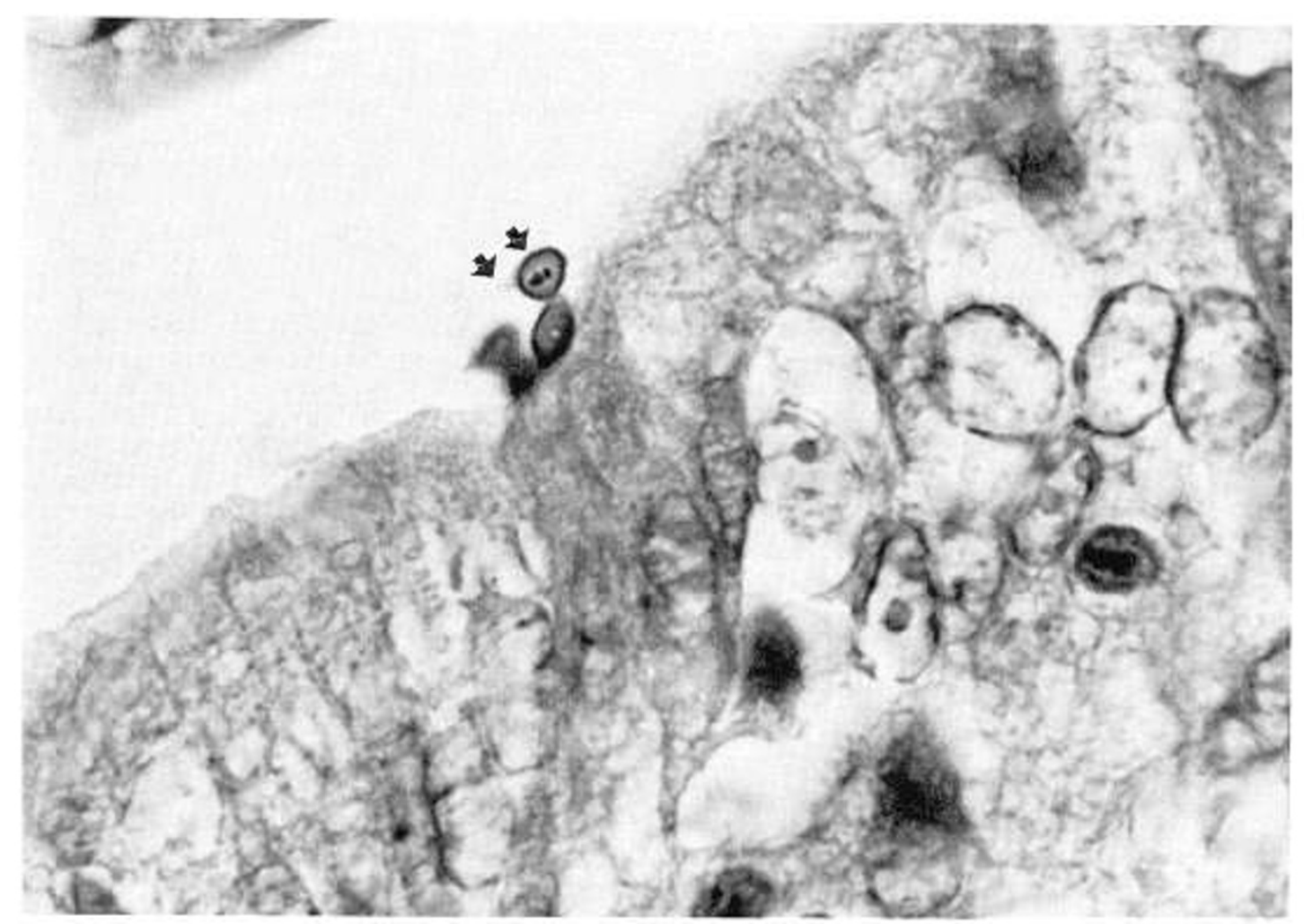

Fig. 2. Intestinal tissue section of an adult rat treated with S.b. for 5 days. Arrows indicate yeast cells in contact with the villus cells (periodic acid-Schiff, $\times 2180$ ). 
statistically significant (mean $\pm \mathrm{SE}: 12.06 \pm 0.9$ S.b. treated versus $10.06 \pm 1.4 \mathrm{U} /$ jejunal segment controls).

To determine a possible effect of $S . b$. treatment on the posttranslational steps of lactase biogenesis, sodium dodecyl sulfate polyacrylamide gel electrophoresis of BBM from young sucklings (14 day old) pretreated with S.b. or with saline were carried out with parallel lactase assay on each molecular weight range. As shown in Figure 3, the protein band corresponding to lactase could be clearly identified in treated $(S . b$.$) and in control (\mathrm{C})$ samples. The distributive pattern of BBM enzymes along the gel is identical to that reported by Raul et al. (13) for the intact 12day-old suckling rat. In both preparations (S.b. and C) the number of protein bands was similar without change in molecular weight. Elution of protein from the lactase band was similar in treated rats $(0.026 \pm 0.003)$ and in controls $(0.021 \pm 0.005$ $\mathrm{mg}$ protein $/ \mathrm{ml}$, eight observations) and the amount of BBM protein layered onto each gel $(200 \mu \mathrm{g})$ was constant. The peak of label incorporation per mg enzyme protein occurred in the gel slices where lactase specific activity was found to be highest (4, 5). These gel slices corresponded topographically to the protein band of lactase as revealed by the staining procedure (Fig. 3). Expressed per mg of lactase (Figure 4), there was no significant difference in the mean incorporation rate of labeled glucosamine into the enzyme precursor between treated rats (mean $\pm \mathrm{SE}$ :

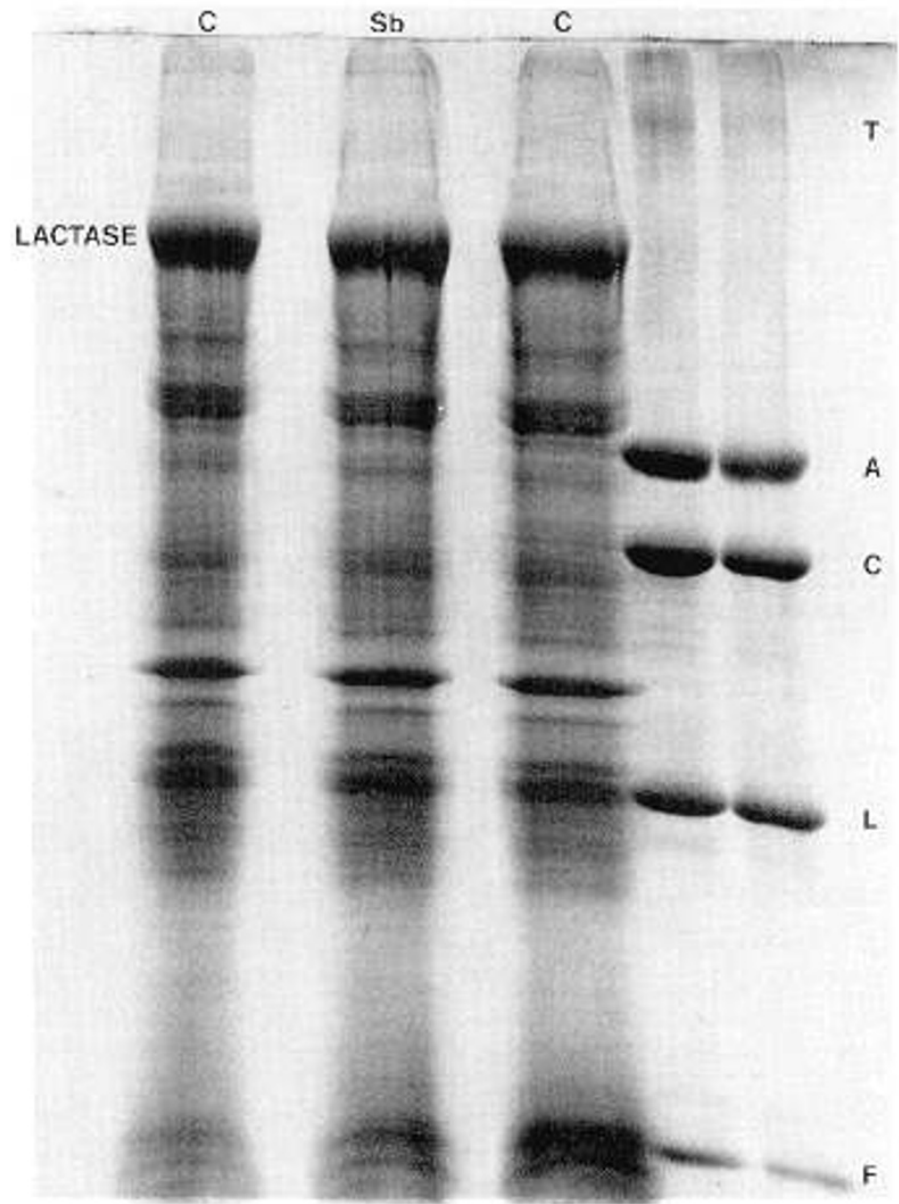

Fig. 3. PAGE electrophoresis (5-15\% gradient) of brush border samples obtained from 14-day-old suckling rats treated with S.b. or with saline $(C)$. Note the large protein band corresponding to neutral lactase. In both preparations $S . h$. and $C$ the number of protein bands is similar, without changes in molecular weight. The first two lines are reference electrophoresis with proteins of known molecular weights. $T$, thyroglobulin 330,$000 ; A$, albumine 67,$000 ; C$, catalase 60,$000 ; L$, lactate deshydrogenase 36,$000 ; F$, ferritin (half unit) 18500 daltons.

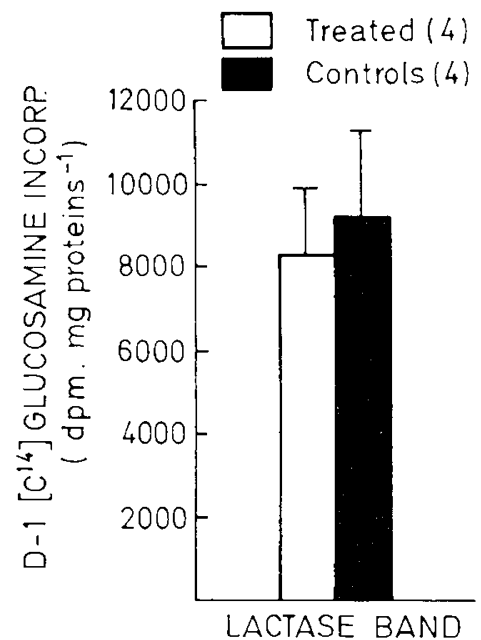

Fig. 4. Expressed per mg of lactase protein, there was no difference in the incorporation rate between treated rats and controls (eight observations).

$8167 \pm 1622 \mathrm{dpm} \cdot \mathrm{mg}$ protein $\left.{ }^{-1}\right)$ and (controls $9602 \pm 1803$ $\mathrm{dpm} \cdot \mathrm{mg}$ protein ${ }^{-1}$, eight observations).

\section{DISCUSSION}

As no adverse or toxic reactions related to $S . b$. treatment have been noted in humans, a lyophilized preparation of $S . b$. is commonly prescribed in some European countries for children and adults with acute gastroenteritis or as adjuvant therapy to antimicrobial drugs $(1-3)$. S.b. cells are resistant to gastric acidity, proteolytic degradation, and antimicrobial drugs. Stool examination of patients treated with $S . b$. usually reveals numerous $S . b$. cells indicating transit in a viable form throughout the gut. Similarly, a study in rats has shown that following oral administration of $S . b$., yeast cells can be found all along the gastrointestinal tract and in the feces (15). On postmortem microscopic examination of rat small intestines, we also found yeast cells in the jejunal lumen which at some places were seen to be in intimate contact with the villus cells. Oral treatment with high doses of the yeast produced no morphological alteration of the small bowel mucosa.

The main finding of our study is that treatment of human volunteers and rats with S.b. was associated with significant increases in the specific and total activity of brush border disaccharidases. The posttrial changes in sucrase activity could be due in part to the exogenous supply of this enzyme provided by the yeast itself, since in vitro assays clearly demonstrated that S.b. cells exhibited an extremely high specific activity for sucrase but virtually no maltase, lactase, $\beta$-galactosidase, or aminopeptidase activity. This is in agreement with in vitro experiments bearing on other species of Saccharomyces that contains several types of $\alpha$-glucosidases including an invertase bound to the mannans of the yeast external cellular membrane $(16,17)$. In weaned conventional and gnotobiotic mice fed yogurt, Besnier et al. (18) noted that the specific and total activity of lactase increased compared to lactose-fed and to heated yogurt-fed controls. These changes were related to the effect of viable microorganisms on the intestinal cells, independent of the exogenous supply of bacterial $\beta$-galactosidase. We found similar changes of lactase activity in both human and rat small intestine treated with viable $S . b$. cells. In the absence of a yeast intrinsic $\beta$-galactosidase activity, these changes were surprising and prompted us to further study the effect $S . b$. cells on the biogenesis of lactase. Ten-dayold suckling rats were choosen for the experiment because at this postnatal age lactase activity is very high, whereas sucrase-isomaltase is virtually absent (19). Disaccharidases are high molec- 
ular weight brush border glycoproteins with rapid turnover rates (20). Luminal agents such as pancreatic enzymes (21), bacteria (22), and extracellular glucosidases from microorganisms (22) are capable of modifying the intestinal turnover rate of these enzymes by affecting either the posttranslational steps of their biogenesis (glycosylation, intracellular translocation, and final plasma membrane incorporation) or their intraluminal degradation rate $(21-23)$.

In adult rats with bacterially contaminated intestine, Jonas et al. (23) have demonstrated that the in vivo incorporation rate of $\left[{ }^{14} \mathrm{C}\right]$-glucosamine into the brush border disaccharidases was markedly enhanced to overcome the increased glycoprotein degradation rate with the result that the disaccharidase activities were maintained at the same level as those found in control rats. Although we did not measure lactase degradation rates, our findings do not suggest an effect of the yeast cells on the final steps of lactase biogenesis or on the enzyme incorporation rate into the BBM. The incorporation rate of labeled glucosamine into lactase precursor which was expressed per unit of brush border enzyme protein was similar in treated rats and controls.

The reason that brush border lactase increases in response to $S . h$. treatment is not known, but possible mechanisms could be a stimulation of protein synthesis at a translational level or an interference of $S . b$. cells or of a metabolite with the proteolytic decay and release of lactase from the microvilli. Mannans of the yeast cell wall could play a role since the increase in disaccharidase activities was observed after treatment with either viable or killed S.h. cells. Alternatively, the possibility that the increase in disaccharidase activity could be due to an increase in enterocyte turnover has to be considered but appears unlikely since we found no difference in mucosal DNA synthesis, measured by the incorporation of $\left[{ }^{3} \mathrm{H}\right]$ thymidine into DNA, between treated rats and controls (unpublished observation). The physiological impact of these intestinal enzyme changes observed in man and rat after treatment with $S . h$. certainly warrants further investigation. For instance it would be of particular interest to assess whether $S . b$. given to patients with acute enteritis exerts a beneficial clinical effect in reducing the intestinal malabsorption of carbohydrates.

Acknowledgments. The authors express their gratitude to Mrs. Nadine De Keyser and Ms. Sylvie Paquet for their expert technical assistance. We also thank Mr. Bernard Hublot and to Mrs. Penelope Brock for helpful comments on the manuscript.

\section{REFERENCES}

1. Essais cliniques contrôlés en double insu de l'Ultra-Levure lyophilisée. Etude multicentrique par 25 médecins de 388 cas 1976 Med Chir Dig 5:401-405
2. Ligny G 1975 Le traitement par l'Ultra-Levure des troubles intestinaux secondaires à l'antibiothérapie. Etude en double aveugle et étude clinique simple. Rev Fr Gastroenterol 1 14:45-50

3. Tempe JD. Steidel AL, Blehaut H. Hasselmann M, Lutun Ph, Maurier F 1983 Prévention par Saccharomyces boulardii des diarrhées de lalimentation entérale à débit continu. Sem Hop Paris 59:1409-1412

4. Buts JP. DeMeyer R, Van Craynest MP. Maldague P 1983 Adaptive response of growing rat small intestine to acute Adriamycin injury. J Pediatr Gastroenterol Nutr 2:159-165

5. Dahlquist A 1964 A method for assay of intestinal disaccharidases. Anal Biochem 7:18-25

6. Lowry OH. Roscbrough NJ, Farr AL. Randall RJ 1951 Protcin measurement with the folin phenol reagent. J Biol Chem 193:265-275

7. Koldovsky O, Asp NG, Dahlquist A 1969 A method for the separate assay of "ncutral" and "acid" $\beta$-galactosidase in homogenates of rat small intestinal mucosa. Anal Biochem 27:409-418

8. Bessey OA. Lowry OH, Brock MJ 1946 A method for the rapid determination of alkaline phosphatase with five cubic millimeters of serum. J Biol Chem $164: 321-329$

9. Maroux S, Louvard D, Baratti J 1973 The aminopeptidase from hog intestinal brush border. Biochim Biophys Acta 321:282-295

10. Schmitz J. Preiser H, Maestracci D. Ghosh BK. Cerda JJ Crane RK 1973 Purification of the human intestinal brush border membrane. Biochim Biophys Acta 323:98-112

11. Laemmli UK 1970 Cleavage of structural proteins during the assembly of the head of bacteriophage T4. Nature 227:680-685

12. Djondjurov L. Holtzer H 1979 A method for recovery of proteins from sodium dodecyl sulfate-polyacrvlamide gels. Anal Biochem 94:274-277

13. Raul F, Simon PM, Kedinger M, Grenier JF. Haffen K 1978 Separation and characterization of intestinal brush border enzymes in adult rats and in suckling rats under normal conditions and after hydrocortisone injection. Enzyme 23:89-97

14. Freiburghaus AU, Havai HP. Green J. Hadorn B 1978 A micromethod for separation and identification of digestive enzymes in brush border membrane fragments of single human intestinal biopsies. Clin Chim Acta 86:227-234

15. Albert O. Massot J. Courtois MC 1977 Etude cinétique quantitative de la répartition d'une levure vivante du genre Saccharomvees à differents niveaux du tractus digestif. Vic Med 18:1604-1606

16. Maurer A. Muehlethaler K 1982 Isolation and localisation of plasma membrane-bound invertase in yeast Sacharomices cerevisiac. Eur J Cell Biol $26: 219-227$

17. Smith WL, Ballow CE 1974 Immunochemical characterization of the mannan component of the external invertase (beta-fructofuranosidase) of Saccharomyces cerevisiae. Biochemistry 13:355-361

18. Besnier MO, Bourlioux P, Fourniat J, Ducluzeau R. Aumaitre A 1983 Influence de l'ingestion de yogourt sur l'activité lactasique intestinale chez des souris axćniques ou holoxéniques. Ann Microbiol (Paris) 134A:219-230

19. Buts JP. De Mever R 1981 Postnatal proximo-distal development of the small bowel mucosal mass in growing rats. Biol Neonate 40:62-69

20. Weiser MM 1983 Intestinal membrane glycoproteins: their synthesis and redistribution during differentiation and possible shedding. J Pediatr Gastroenterol Nutr 2(suppl 1):SI57-S153

21. Alpers DH. Tedesco FJ 1975 The possible role of pancreatic proteases in the turnover of intestinal brush border proteins. Biochim Biophys Acta 401:2840

22. Prizont R 1981 Glycoprotein degradation in the blind loop syndrome. Identification of glycosidases in jejunal contents. $J$ Clin Invest 67:336-344

23. Jonas A. Flanagan PR. Forstner GG 1977 Pathogenesis of mucosal injury in the blind loop syndrome. Brush border enzyme activity and glycoprotein degradation. J Clin Invest 60:1321-1330 